https://zakon.rada.gov.ua/laws/show/v0007700-08\#Text (data zvernennya 23.08.2020). (in Ukrainian)

12. Postanova Verhovnogo Sudu u skladi postijnoyi kolegiyi suddiv Tretoyi sudovoyi palati Kasacijnogo civilnogo sudu vid 08 serpnya 2019 r. u spravi № 683/825/15-c. URL: http://reyestr.court.gov.ua/Review/83616908 (data zvernennya 24.08.2020). (in Ukrainian)

13. Postanova Verhovnogo Sudu u skladi kolegiyi suddiv Drugoyi sudovoyi palati Kasacijnogo civilnogo sudu vid 17 zhovtnya 2018 r. u spravi № 727/3905/16-c. URL: http://reyestr.court.gov.ua/Review/77248974 (data zvernennya 23.08.2020). (in Ukrainian)

M. Bondareva, PhD (Law), Associate Prof.,

S. Rabovska, PhD (Law), Associate Prof

Taras Shevchenko National University of Kyiv, Kyiv, Ukraine

\title{
THE ELIMINATION FROM THE RIGHT TO INHERITANCE: THEORY AND PRACTICE
}

The article deals with the legal regulation for removal from the right to inheritance and law enforcement of the norm of Art. 1224 of the Civil Code of Ukraine. The study aims at developing the theoretical foundations of the application of this legal norm on the basis of analysis of legislation and case law.

Such methods and approaches as systematic analysis and competent legal interpretation have been applied.

The Civil Code of Ukraine regulates cases and removal of grounds for the right to inheritance. Article 1224 of the Civil Code of Ukraine is applied to heirs at law; it distinguishes cases and grounds for exclusion from the right to inheritance by various criteria. However, what is typical for the countries of the continental group, the law needs to be clarified, first of all at the level of law enforcement practice.

The highest jurisdiction of Ukraine - the Supreme Court of Ukraine and the Supreme Court, made appropriate clarifications and interpretations of relevant legal norms at the general theoretical level (decision of the Plenum of the Supreme Court of Ukraine) and at the level of unification of general practice through expressing a legal position in specific cases.

Such interpretation should be considered clearly and sufficiently for further processing. However, judicial interpretation is not competent to correct legislative inaccuracies. And the case law itself is characterized by a tautology and inconsistency, when the departure from the previously adopted legal position is disguised under the difference of legal and factual grounds of the claim.

The results of such miscalculations include variability of methods of judicial protection for the heirs of the first turn (paragraph 2, part 3 of Article 1224 and part 5 of Article 1224 of the Civil Code of Ukraine) and procedural difficulties in proving claims - proving the testator's helplessness, address need assistance from the defendant, etc. In addition to legal uncertainty, which results in the poor functioning of institutions of exclusion from the right to inherit, this state of affairs creates grounds for abuse of rights.

The authors propose measures to solve the problem, which can be divided into several groups.

The first concerns amendments to Paragraph 2, Part 3 of Art. 1224 and Part 5 of Art. 1224 of the Civil Code of Ukraine: in terms of the subject composition, in particular, the permission of the heirs of other than the first turn, the order of inheritance, to sue on the basis of Paragraph 2 of part 3 of Article 1224 of the Civil Code of Ukraine.

The second is aimed at intensifying the institution provided by Paragraph 2 of Part 3 of Article 1224 of the Civil Code of Ukraine, inter alia, due to the uniformity and consistency of judicial practice. The introduction of the principle of participation in inheritance by bona fide heirs as a reward for their care of the testator, and the relatively easy removal of the right to inherit those who did not show such care, will also contribute to the revival of law enforcement.

Finally, the third group of measures is related to the promotion of inheritance through wills, which will limit the number of disputes in inheritance cases (mainly cases of invalidation of the will) and put an end to the issue of exclusion from the right to inherit.

Keywords: legal inheritance, heir, testator, removal from inheritance, obligation to maintain the testator, evasion of maintenance, helplessness.

Bulletin of Taras Shevchenko National University of Kyiv.

Legal Studies, 2020; 3 (114): 9-13

УДК: 342.98

DOI: https:doi.org/10.17721/1728-2195/2020/3.114-2
ISSN 1728-2195

(C) Taras Shevchenko National University of Kyiv,

Publishing center "Kyiv University", 2020

Київський національний університет імені Тараса Шевченка, Київ, Україна

\section{ОСОБИСТА БЕЗПЕКА ПРАЦІ ДЕРЖАВНИХ СЛУЖБОВЦІВ В УКРАЇНІ}

Статтю присвячено дослідженню проблеми особистої безпеки праці державних службовців в Україні. Доведено актуальність, новизну наукового дослідження та висвітлено його соціальну значущість. Визначено особливу специфіку праці державних службовців. Наведено значення та роль особистої безпеки праці такої категорії працівників. Висвітлено науково-правове закріплення особистої безпеки праці державних службовців. Розглянуто наукові погляди на поняття "особиста безпека". Здійснене узагальнення законодавства та практики дозволило запропонувати поняття "особистої безпеки праці державних службовців". Проаналізовано вплив особистої безпеки на професійну діяльність державних службовців. Показано важливість забезпечення високого рівня особистої безпеки державних службовців при здійсненні ними своїх повноважень. Указано на загрози та ризики забезпечення особистої безпеки праці. Виявлено можливі небезпеки для державних службовців при здійсненні службових повноважень. Виведено види небезпек, що порушують безпечне функціонування державних службовців та запропоновано способи покращення процесу регулювання їх особистої безпеки праці. Наведено шляхи усунення ризиків особистої безпеки праці державних службовців, які сприятимуть вирішенню конкретних проблем, усуненню існуючих теоретичних суперечностей у полі особистої безпеки праці або його окремих ділянках та забезпечать такій категорії працівників максимальну віддачу у здійсненні своїх повноважень і професійне зростання. Наведено шляхи гарантування особистої безпеки праці у процесі нормативно-правового закріплення. Розглянуто захист кожного працівника у випадках порушення особистої безпеки. Доведена необхідність подальшого наукового дослідження та нормативного закріплення безпеки праці державних службовців, що максимально гарантуватимуть захист державних службовців в особистому просторі під час виконання обов'язків та завдань.

Ключові слова: державні службовці, службові повноваження, особиста безпека, безпека праці, наукові погляди, нормативно-правове закріплення, ризики, небезпеки, пропозиції покращення.

встУп. Закон України "Про державну службу" визначає державну службу, як публічну, професійну, політично неупереджену діяльність із практичного виконання державними службовцями завдань і функцій держави, а державного службовця закріплює, як громадянина
України, який займає посаду державної служби в органі державної влади чи іншому державному органі, його апараті (секретаріаті), одержує заробітну плату за рахунок коштів державного бюджету та здійснює службові повноваження, установлені відповідно до своєї посади, 
які безпосередньо пов'язані з виконанням функцій і завдань такого державного органу, а також дотримується принципів державної служби [1]. Такі особливості породжують вагомість праці державних службовців.

Специфіка діяльності державних службовців ґрунтується на серйозності державних ситуацій, складності завдань та високій соціальній відповідальності перед суспільством. Це насамперед потребує максимальної особистої захищеності таких працівників при виконанні ними службових повноважень. Однією з вагомих умов професійного успіху державних службовців є безпека життя та здоров'я, які проголошені в державі найвищими соціальними благами та багатством кожної людини.

Право людини на особисту безпеку $є$ найпершим i найціннішим правом людини, від якого залежать усі інші права. Про це свідчить весь досвід людства, накопичений протягом історії. Це право по своїй суті становить основу всіх прав. Користування ним $€$ передумовою для використання інших прав людини.

Нині питанню забезпечення особистої безпеки праці держава приділяє недостатньо уваги, що не дозволяє державним службовцям мати впевненість у своїх діях, адже працівники, які впевнені в гарантуванні особистої безпеки праці, максимально віддано виконують доручені завдання та професійно здійснюють обов'язки.

Видатні правознавці та філософи Г.В.Ф. Гегель, Т. Гоббс, В. Гумбольдт, Р. Моль, І. А. Ільїн у своїх наукових працях забезпечення особистої безпеки кожного підданого, кожного громадянина визнавали священним обов'язком держави.

Г.В.Ф.Гегель зазначав таке: впевненість людей указує, що існування держави забезпечить існування особливого інтересу, та звичка приховує від нас те, на чому базується наше існування. У ситуації, коли людина вночі виходить спокійно на вулицю, вона і не думає про те, що все могло б бути і не так. Оскільки така звичка до безпеки стала їі другою натурою, і ніхто не думає про те, що це є результатом лише дій певних особливих установ [2, с. 293].

І. А. Ільїн писав: "Ніхто не може бути виключеним із державної системи захисту, турботи і сприяння" [3, с. 247].

Відома дослідниця В. П. Васьковська подає класифікацію видів безпеки, де особисту безпеку ставить на перше місці серед громадської (політичної), кримінологічної, екологічної, майнової [4, с. 135].

ВИКЛАД ОСНОВНОГО МАТЕРІАЛУ. ЗвертаючИ увагу на значущість та важливість праці державних службовців, які в першу чергу працюють із державною таємницею, такі працівники постійно відчувають на собі ризики, які спричиняють шкоду біологічній діяльності організму. У процесі виконання службових повноважень державні службовці перебувають у зоні підвищеної конфлліктності та напруги, яка становить загрозу особистій безпеці фізичній та майновій. Це змушує державу максимально забезпечити особисту безпеку праці таких працівників, не лише під час несення державної служби, а й при щоденних буденних справах, у вільний від роботи час.

На сьогодні в законодавстві України увага концентрується не на захисті державних службовців від втручання в роботу та посягання на здоров'я і життя, а на виявленні неправомірних діянь та порушень присяги державних службовців. Причому в нормативноправових актах не закріплено чітких дій працівників для уникнення ризиків при здійсненні службових повноважень та засобів гарантування особистої безпеки державних службовців.

У правовому науковому полі все частіше відбуваються дослідження проблеми особистої безпеки. Цій тематиці частково присвячені окремі праці таких відо- мих науковців: В. Р. Андросюк, В. Т. Білоус, Т. М. Вахонєва, С. К. Делікатний, Л.І.Казміренко, Т. М. Краснянська, В. О. Лефтеров, В. Л. Манилов, М. І. Іншин, Г. Г. Почепцов, П. Я. Пригунов, Г. П. Ситник, Г. О. Юхновець та ін. Однак специфріка особистої безпеки праці державних службовців потребує подальшого системного дослідження, адже й досі залишається недостатньо теоретично розглянутою.

Отже, передусім проведемо аналіз поняття "особиста безпека" та спробуємо застосувати його до специфіки праці державних службовців, що в подальшому дозволить вивести чітке розуміння сутності особистої безпеки праці державних службовців.

Так, В. С. Джигирей та В. Ц. Жидецький розглядають безпеку людини як певний стан ії̈ діяльності, за якого з певною вірогідністю виключається можливість нанесення ушкодження здоров'ю [5; 6, с. 342].

Протилежне бачення має С. К. Делікатний, який не виключає можливості такої загрози, та під безпекою особи розуміє такий стан захищеності її життєво важливих інтересів від фрізичного, психологічного або ж іншого насильницького посягання, що загрожує нанесенням шкоди та дозволяє їй приймати рішення і здійснювати відповідні заходи захисту" [7].

Російська дослідниця Т. М. Краснянська, розглядає особисту безпеку індивіда, як стан відкритості та захищеності, адекватний до впливу чинників і провідних потреб, що забезпечує йому, з одного боку, фрізичну i психічну цілісність, а з іншого, - можливість відтворення та продукування різних цінностей, які підтримують процес його особистісного розвитку [8, с. 152].

На думку В. О. Лефртерова, особиста безпека $є$ інтегрованим захистом прав, свобод, життя і здоров'я кожної людини, шляхом забезпечення фрізичної, духовної, інтелектуальної безпеки особистості. Зазначає при цьому, що стратегія особистої безпеки людини є загальною моделлю поведінки ії в забезпеченні власної безпеки та дає специфічні загальні знання у сфері безпеки і виживання, але не використовує конкретизацію явища. Та вказує, на необхідність створення стратегії особистої безпеки з урахуванням особливих індивідуальних якостей кожної людини, що може надати в подальшому їй можливість вижити в будь-яких небезпечних для неї ситуаціях [9].

Більш влучне, на наш погляд, $€$ бачення О. М. Кретчак, який у своєму дослідженні розглядає безпеку особи, як стан захищеності життєво важливих інтересів індивіда, його прав та свобод, відсутність небезпеки для його життя [10, с. 5]. Він відкидає існування людини серед небезпеки, а вказує на фрормування такого механізму особистої безпеки, який би попередив існування будь-яких загроз.

С. В. Городянко, аналізуючи безпеку працівників високо ризикованих небезпечних професій, розглядав профресійну безпеку працівників органів внутрішніх справ і дійшов висновку, що характеристика службової діяльності залежить від стану захищеності праці та безпосередньо пов'язана $з$ реальним розміром професійного ризику та здібністю осіб начальницького та рядового складу звести цей ризик до можливої межі при вирішенні професійно-службових завдань [11]. На наш погляд, це дуже вузьке розуміння, при застосуванні до категорії державних службовців у цілому, оскільки вважаємо, що ризики особистої безпеки повинні не лише керівники зводити до мінімуму, а в першу чергу має гарантувати держава шляхом нормативно-правового забезпечення.

Проаналізувавши різні погляди на поняття "особиста безпека", ми розглянемо "особисту безпеку праці 
державних службовців", як стан захищеності таких працівників від небезпечних чинників професійної діяльності, який, по-перше, допоміг би уникнути будь-яких ризиків для здоров'я та посягань на життя, шляхом забезпечення їх фрізичного, психічного та духовного стану, по-друге, став стимулом для успішного здійснення своїх професійних повноважень та поставлених завдань.

У широкому сенсі слова особиста безпека праці державних службовців $€$ таким станом кожного працівника, що є вільним від будь-якої небезпеки щодо своїх прав та інтересів.

Після аналізу поняття, можемо перейти до аналізу впливу особистої безпеки на професійну діяльність державних службовців та його нормативно-правового закріплення.

Загалом особисту безпеку розуміємо як стан захищеності особи від внутрішніх та зовнішніх загроз та ризиків, при якому забезпечується ії̈ нормальне функціонування. Поняття "небезпека" у значенні як похідне від "посягання", "загроза", "ризик".

Справді надійна особиста безпека державних службовців може бути досягнута лише через усунення причин створення ризиків та загроз для них, їх прав та свобод. Забезпечення особистої безпеки праці залежить насамперед від самого працівника, як він виявляє ризики під час виконання завдань, як справляється з непередбачуваними небезпечними ситуаціями. Та вочевидь багатьом загрозам, які існують у суспільстві, державні службовці не підвладні. Це потребує чіткого нормативно-правового захисту та безперервного дослідження забезпечення високого рівня особистої безпеки праці, без якої було б безпредметним питання про дотримання інших прав та свобод людини.

Беззаперечно, особиста безпека праці державних службовців може бути досягнута шляхом виявлення та подальшого усунення ризиків і загроз у праці, які супроводжуються безправ'ям і беззаконням. Будь-яка особа, плануючи свою погрозу, посягає не лише на особисту безпеку праці державних службовців, а й на суспільну безпеку як захищений кримінальним законом суспільний і державний інтерес.

Гарантування особистої безпеки праці державних службовців, запобігання порушенню прав на особисту безпеку праці та відновлення права (у разі втрати) відбувається шляхом закріплення в нормативно-правових актах законодавства України. Тобто право на особисту безпеку праці - це певні гарантії, обмеження, правові інститути, державні структури й механізми, які забезпечують захист працівника від ризиків і небезпек.

Стаття 3 Конституції України визнає людину, її життя, здоров'я, гідність, честь, безпеку та недоторканність найвищими соціальними цінностями. Частина 2 ст. 27 надає право людині особисто забезпечувати свою безпеку, а ч. 1 ст. 49 - право на охорону здоров'я. А щодо належних і безпечних умов праці Конституція закріплює таке право у ч. 4 ст. 43 [12].

Аналізуючи конституційні норми, можна зробити висновок про те, що таке законодавче закріплення норм статей забезпечує право кожного на особисту безпеку, яку можна забезпечувати власними намаганнями, законним шляхом та зверненнями за допомогою до держави.

У цілому право на особисту безпеку праці державних службовців передбачає закріплену нормами Конституції сукупність юридичних можливостей кожного, пов'язаних із реалізацією волі і особистим захистом від посягань із боку інших індивідів. Забезпечення високого рівня особистої безпеки праці покладається на кожного особисто державного службовця, як виконавця трудових обов'язків, і на державу, як основного суб'єкта тру- дових правовідносин. Частина 1 ст. 27 визначає обов'язок держави захищати кожне життя людини [12].

Законодавство повинно детально розкрити особливості забезпечення особистої безпеки державних службовців. Закон України "Про державну службу" не розкриває поняття "особиста безпека державних службовців" та членів їхніх сімей, а лише ст. 7 розділу 2 Закону України "Про державну службу" зазначає, що одним із ключових прав державних службовців $є$ право на повагу до своєї особистості, гідності, честі, шанобливе та справедливе ставлення з боку керівництва, колег та інших людей [13].

Закон України "Про державну охорону органів державної влади України та посадових осіб" поширюється на об'єкти державної влади, але відносно посадових осіб, які працюють у державних органах та не є державними службовцями [14]. А закону, який би захищав працівників, що мають статус державних службовців, при виконанні своїх повноважень, на сьогодні немає. Та така категорія працівників безсумнівно теж повинна мати можливість користуватися охороною під час виконання особливо ризикових і таємних завдань, щоб уникнути небезпеки для свого життя.

Основними зовнішніми загрозами та ризиками, при здійсненні службових повноважень, є такі:

1) спричинення певної шкоди фрізичному та психологічному здоров'ю;

2) насильницьке порушення тілесної цілісності працівника;

3) погроза вбивства;

4) знищення чи пошкодження майна;

5) залякування;

6) погрози та нанесення шкоди рідним.

На ступінь захищеності великим чином впливають такі фрактори: оцінка актуальності кожної із загроз для власної безпеки праці та рівень очікувань працівника стосовно надійності захисту з боку держави.

Та, при подальшому дослідженні та законодавчому закріпленні терміну "особиста безпека державних службовців", наведеними ризиками не треба обмежуватись.

На відміну від зовнішніх загроз, які виникають від незалежного від особи чинника, внутрішні загрози можемо розглядати з позиції самозбереження, коли в результаті сильного інформаційного чи фрізичного перенавантаження чи переробітку, з'являється негативний вплив на здоров'я. На наш погляд, найкращим способом забезпечення особистої безпеки праці державних службовців є попередження ії̈ негативних проявів ще на початковій стадії зародження.

Отже, враховуючи розгляд основних загроз, у трудових відносинах державних службовців можна виділити такі види небезпек:

1) залежна від самого працівника - з'являється при перевантаженні, виснаженні, переробітку працівника;

2) підбурювана - з'являється за прояву негативних рис поведінки працівника, яка провокує інших на конфліктну ситуацію та агресію;

3) евентуальна - з'являється при відповідних ситуаціях із конфоліктними суб'єктами.

Нині спостерігається відсутність системного підходу у системі протидії небезпекам праці державних службовців, ігнорування якого на законодавчому рівні може призвести до виникнення загроз в особистій безпеці кожного державного службовця.

Кримінальний кодекс України убезпечує та захищає кожного через норми і Загальної, і Особливої частин. 3 урахуванням ст. 11 [15], можна визначити злочином діяння, яке заподіяло істотну шкоду фізичній особі та яке могло б заподіяти таку шкоду, тобто порушило осо- 
бисту безпеку, створило для неї загрозу заподіяння (життю, здоров'ю, свободі або майну) істотної шкоди на робочому місці чи у вільний від роботи час.

3 огляду на це, питання забезпечення особистої безпеки праці державних службовців стає все більш актуальним та набуває особливої гостроти, оскільки вказана категорія працівників, у першу чергу як громадяни України має невід'ємні конституційні права на безпечні, належні та здорові умови праці, права на здоров'я та життя, зокрема, у процесі трудової діяльності.

Для регулювання особистої безпеки праці державних службовців у державних органах пропонуємо:

1) переглянути нормативно-правове забезпечення вказаної категорії працівників;

2) розробити проєкт Закону "Про безпеку праці державних службовців в Україні" з розділом "Особиста безпека праці", який би максимально гарантував захист працівників в особистому просторі;

3) включити до навчальних планів підготовки цієї категорії працівників навчальну дисципліну "Особиста безпека державних службовців";

4) створити службу в кожному державному органі, яка б забезпечувала інформування працівників про права в їх особистому захисті та проводила інструктажі способу поводження, щоб не допустити ризиків.

Потрібно ніколи не забувати, що методика діяльності державних службовців завжди пов'язана з ризиком у політичній, соціальній, правовій, економічній та фрінансовій ссрерах, який є ймовірним в їх роботі. Тож особиста безпека праці державних службовців найчіткіше буде забезпечуватися самозбереженням працівника та чітким нормативно-правовим закріпленням способів забезпечення особистої безпеки від зовнішніх та внутрішніх загроз. Це сприятиме стабільному функціонуванню працівників та можливості здійснення успішної професійної діяльності.

ВИСНОВКИ. Беззаперечно, безпека кожного державного службовця на національному рівні $€$ складовою безпеки держави. Отже, на сучасному етапі будівництва правової держави, важливим $€$ завдання максимального захисту особистої безпеки праці державних службовців, як складової безпеки інтересів держави.

Діяльність державних службовців є тим специфічним видом праці, що призводить до порушення його особистої безпеки праці. Під нею розуміємо такий стан захищеності особистого життя, здоров'я, майна, ділової репутації від небезпечних ризиків професійної діяльності, який, з одного боку, забезпечував би їх фрізичне, психічне та духовне здоров'я, а з іншого надавав би можливість успішного виконання службових обов'язків і службових завдань, нормального фрункціонування та безперервного профресійного розвитку.

Вважаємо, що правове забезпечення особистої безпеки праці державних службовців повинне бути інтегроване не лише в кадрову політику управління в державних органах влади як чітка система протидії загрозам - фізичному, психологічному стану працівників чи нанесенню матеріальної шкоди, а й у першу чергу, має охоронятися державою шляхом нормативно-правового гарантування.

Забезпечення високого рівня психічного та фрізичного здоров'я в поєднанні з теоретичною підготовкою та професіоналізмом дадуть змогу державним службовцям завжди бути впевненими в особистій безпеці і свій робочий час присвячувати здійсненню службових повноважень.

Негативні тенденції посягань на особисту безпеку праці службовців державного апарату спонукають до нових досліджень даної тематики.

У подальшому, вбачаємо, саме застосування запропонованих нами безпекових методів покращення добре забезпечить відчуття особистої безпеки праці державних працівників, порівняно з будь-якими іншими політичними чи соціальними способами.

\section{Список використаних джерел}

1. Про державну службу: Закон України №889-VIII від 10 грудня 2015 р. // Відомості Верховної Ради. - 2016. - № 4. - Ст. 43.

2. Гегель Г. В. Ф. Философия права / Г.В.Ф.Гегель; пер. с нем. ред. и сост. Д. А. Керимов и В. С. Нерсесянц. - М. : Мысль, 1990. - 524 с.

3. Ильин И. А. Путь к очевидности / И. А. Ильин. - М., 1993. - 247 с

4. Васьковська В. П. Складові елементи поняття безпеки людини В структурі права людини на безпеку / В. П. Васьковська // Наук. вісн. Юридичної академії МВС - Дніпропетровськ. - 2004 - № 4 - С. 134-140.

5. Джигирей В. С. Безпека життєдіяльності: підручник для студ. вищ. навч. закладів / В. С. Джигирей, В. Ц. Жидецький; Науковометодичний центр вищої освіти; Українська академія друкарства; Український держ. лісотехнічний ун-т. - 4-те вид., допов. - Л. : Афіша, 2001. - 256 c

6. Жидецький В.Ц. Основи охорони праці / В. Ц. Жидецький ; Українська академія друкарства. Український держ. лісотехнічний ун-т. - Л. : Афріша, 1999. - 347 с.

7. Деликатный С. К. Основы профессиональной и психологической подготовки сотрудников личной охраны / С. К. Деликатный, Ж. Ю. Половникова, П. Я. Прыгунов. - К. : Альфа-Щит, 1998. - 531 с.

8. Краснянская Т. М. Личная безопасность человека в проблемном поле психологии безопасности / Т. М. Краснянская // Вестник Ставропольского гос. ун-та. - 2005. - Вып. 40. - С. 145-152.

9. Лесртеров В.А. К вопросу о психологическом обеспечении личной безопасности работников органов внутренних дел / В. А. Лесттеров // Вісн. Національної академії Державної прикордонної служби України: електрон. наук. фах. вид. - 2010. - Вип. 3. URL: http://www.nbuv.gov.ua/e-journals/Vnadps/2010_3/10lvaovd.p (дата звернення: 20.08.2020)

10. Кретчак О.М. Психологічний аналіз професійної діяльності міліціонерів ДСО при МВС України та визначальні умови її удосконалення : автореф. дис. на здобуття наук. ступеня канд. психол. наук : 19.00.06 "Юридична психологія" / О.М.Кретчак; Нац. акад. внутр. справ України. - К., 2003. - 17 с.

11. Городянко С. В. Організаційно-правове забезпечення безпеки діяльності працівників ОВС України : автореф. дис. на здобуття наук. ступеня канд. юрид. наук : 12.00.07 "Адміністративне право і процес; фінансове право; інформаційне право" / С.В.Городянко; Київський нац. ун-т внутрішніх справ. - К., 2007. - 20 с.

12. Конституція України: Закон України № 254к/96-ВР від 28 червня 1996 р. // Відомості Верховної Ради України. - 1996. - № 30. - С. 141.

13. Про державну службу: Закон України № 889-VIII від 10 грудня 2015 р. // Відомості Верховної Ради. - 2016. - № 4. - С. 43.

14. Про державну охорону органів державної влади України та посадових осіб: Закон України № 160/98-ВР від 04 березня 1998 р. // Відомості Верховної Ради України. - 1998. - № 35. - С. 236.

15. Кримінальний кодекс України: Закон України від 05 квітня 2001 р. № 2341-ІІІ // Відомості Верховної Ради України. - 2001. - № 2526. - C. 131.

References

1. Pro derzhavnu sluzhbu: Zakon Ukrai'ny №889-VIII vid 10 grudnja 2015 r. Vidomosti Verhovnoi' Rady. 2016. № 4. S.43. (in Ukrainian)

2. Gegel' G.V.F. Filosofija prava (Philosophy of law). Per. s nem., Red. i sost. D. A. Kerimov i V. S. Nersesjanc. Moskva: Mysl'. 1990. 524 s. (in Russian)

3. Il'in I.A. Put' $k$ ochevidnosti (The path to the obvious.). Moskva.1993.247 s. (in Russian)

4. Vas'kovs'ka V.P. Skladovi elementy ponjattja bezpeky ljudyny $v$ strukturi prava ljudyny na bezpeku (Components of the concept of human security in the structure of the human right to security.). Naukovyj visnyk Jurydychnoi' akademii' MVS. Dnipropetrovs'k. 2004. № 4. S.134-140. (in Ukrainian)

5. Dzhygyrej V.S. Bezpeka zhyttjedijal'nosti: pidruchnyk dlja stud. vyshh. navch. zakladiv (Life safety: a textbook for students. higher textbook institutions) / V. S. Dzhygyrej, V. C. Zhydec'kyj; Naukovo-metodychnyj centr vyshhoi' osvity; Ukrai'ns'ka akademija drukarstva; Ukrai'ns'kyj derzh. lisotehnichnyj un-t. - 4-e vyd., dop. L. : Afisha, 2001. 256 s. (in Ukrainian)

6. Zhydec'kyj V.C. Osnovy ohorony praci Ukrai'ns'ka akademija drukarstva (Fundamentals of labor protection Ukrainian Academy of Printing. Ukrainian state.). Ukrai'ns'kyj derzh. lisotehnichnyj un-t. L. : Afisha, 1999. 347 s. (in Ukrainian)

7. Delikatnyj S.K., Polovnikova Zh.Ju., Prygunov P.Ja. Osnovy professional'noj i psihologicheskoj podgotovki sotrudnikov lichnoj ohrany (Fundamentals of professional and psychological training of personal security officers). Kiev: "Al'fa-Shhit", 1998. 531 s. (in Russian)

8. Krasnjanskaja T.M. Lichnaja bezopasnost' cheloveka v problemnom pole psihologii bezopasnosti (Personal security of a person in the problem field of security psychology). Vestnik Stavropol'skogo gosudarstvennogo universiteta. 2005. Vyp. 40. C.145-152. (in Russian)

9. Lefterov V.A. K voprosu o psihologicheskom obespechenii lichnoj bezopasnosti rabotnikov organov vnutrennih del (On the issue of psychological support for the personal safety of employees of internal affairs bodies). Visnik Nacional'noï akademiï Derzhavnoï prikordonnoï sluzhbi Ukraïni: elektron. nauk. fah. vid. / gol. red. Romanishina L.M. 2010. Vip.3. http://www.nbuv.gov.ua/e-journals/Vnadps/2010_3/10lvaovd.p (data zvernennja: 20.08.2020). (in Russian) 
10. Kretchak O.M. Psyhologichnyj analiz profesijnoi' dijal'nosti milicioneriv DSO pry MVS Ukrai'ny ta vyznachal'ni umovy i'i' udoskonalennja (sychological analysis of professional activity of policemen of DSO at the Ministry of Internal Affairs of Ukraine and defining conditions of its improvement): avtoref. dys. na zdobuttja nauk. stupenja kand. psyhol. nauk : spec. 19.00.06 "Jurydychna psyhologija". Nac. akad. vnutr. sprav Ukrai'ny. Kyi'v. 2003. 17 s. (in Ukrainian)

11. Gorodjanko S.V. Organizacijno-pravove zabezpechennja bezpeky dijal'nosti pracivnykiv OVS Ukrai'ny (Organizational and legal security of the activities of police officers of Ukraine): avtoref. dys. na zdobuttja nauk. stupenja kand. juryd. nauk : spec. 12.00.07 "Administratyvne pravo i proces; finansove pravo; informacijne pravo". Kyi'vs'kyj nacional'nyj un-t vnutrishnih sprav. Kyi'v. 2007. 20 s. (in Ukrainian)

12. Konstytucija Ukrai'ny: Zakon Ukrai'ny № 254k/96-VR vid 28 chervnja 1996 r. Vidomosti Verhovnoi' Rady Ukrai'ny. 1996. № 30. S. 141. (in Ukrainian)

\section{Voitiuk, PhD Student}

Taras Shevchenko National University of Kyiv, Kyiv, Ukraine

13. Pro derzhavnu sluzhbu: Zakon Ukrai'ny № 889-VIII vid 10 grudnja 2015 r. Vidomosti Verhovnoi' Rady. 2016. № 4. S. 43. (in Ukrainian)

14. Pro derzhavnu ohoronu organiv derzhavnoi' vlady Ukrai'ny ta posadovyh osib: Zakon Ukrai'ny №160/98-VR vid 04 bereznja 1998 r. Vidomosti Verhovnoi' Rady Ukrai'ny. 1998. № 35. S. 236. (in Ukrainian)

15. Kryminal'nyj kodeks Ukrai'ny: Zakon Ukrai'ny vid 05 kvitnja 2001 r. № 2341-III. Vidomosti Verhovnoi' Rady Ukrai'ny. 2001. № 25-26. S. 131. (in Ukrainian)

Received: $20 / 08 / 2020$

1st Revision: $07 / 09 / 2020$

Accepted: $18 / 09 / 2020$

The article is devoted to the issue on personal safety of civil servants in Ukraine. The relevance, novelty of scientific research and its social significance are proved. The special specifics of the work of civil servants are determined. The importance and role of personal safety of this category of workers are given. The scientific and legal consolidation of personal safety of civil servants is highlighted. Scientific views on the concept of "personal security" are considered. The paper addresses the best experience on the basis of which the concept and essence of "personal safety of civil servants" is offered. The influence of personal safety on the professional activity of civil servants is analyzed. The importance of ensuring a high level of personal security of civil servants in the exercise of their powers is stated. Threats and risks of ensuring personal safety are indicated. Possible dangers for civil servants in the exercise of official powers have been identified. The types of dangers that disrupt the safe functioning of civil servants are derived. Ways to improve the process of regulating the personal safety of civil servants are proposed. There are ways to eliminate the risks of personal safety of civil servants, which will help solve specific problems, eliminate existing theoretical contradictions in the field of personal safety or in its individual areas and provide this category of employees maximum efficiency in the exercise of their powers and professional growth. Ways to guarantee personal safety in the process of legal consolidation are given. The protection of each employee in cases of violation of personal safety is considered. The necessity of further scientific research and normative consolidation of labor safety of civil servants, which will maximally guarantee the protection of civil servants in personal space in the performance of duties and tasks, has been proved.

Keywords: civil servants, official powers, personal safety, labor safety, scientific views, legal consolidation, risks, dangers, suggestions for improvement.

Bulletin of Taras Shevchenko National University of Kyiv.

Legal Studies, 2020; 3 (114): 13-18

УДК: 340.15(477)"1743"(094.1)

DOI: https:doi.org/10.17721/1728-2195/2020/3.114-3
ISSN 1728-2195

(C) Taras Shevchenko National University of Kyiv,

Publishing center "Kyiv University", 2020

P. Гринюк, д-р юрид. наук, ректор ORCID ID: 0000-0003-0158-8363

Донецький національний університет імені Василя Стуса, Вінниця, Україна,

Б. Кіндюк, д-р юрид. наук, зав. лаб. ORCID ID: 0000-0001-8519-4649

Одеський державний університет внутрішніх справ, Одеса, Україна

\section{"ПРАВА, ЗА ЯКИМИ СУДИТЬСЯ МАЛОРОСІЙСЬКИЙ НАРОД" 1743 р.: ОСОБЛИВОСТІ ПОБУДОВИ ТА КІЛЬКІСНІ ПОКАЗНИКИ}

В Україні проходять складні й неоднозначні процеси реформування правової системи, у межах якої була прийнята значна кількість нормативно-правових актів, що в багатьох випадках не враховують національних особливостей та традицій українського народу. У таких умовах необхідно звернутися до досвіду, накопиченого в часи існування Козацько-гетьманської держави, в якій проходила кодифікація українського права, результатом чого стала підготовка "Прав, за якими судиться малоросійський народ" 1743 р. Ця пам'ятка права мала упорядкувати законодавчу систему, замінити значну кількість джерел права та не допустити поширення імперських правових норм. Положення пам'ятки вплинули на зміст, прийнятого на З'ізді у м. Глухові козацької старшини у грудні 1763 р. "Прошения малороссийского шляхетства и старшин вместе с гетманом о восстановлении разных старинных прав Малороссии", в якому багато положень збігалися зі змістом глав "Прав, за якими судиться малоросійський народ" 1743 p.

Для дослідження давньої пам'ятки права вперше використано методику кількісних показників, яка передбачала розрахунки кількості знаків у цілому документі, главах, артикулах та оцінку нерівномірності розподілення матеріалу. 3 метою проведення порівняльного аналізу використано подібну інформацію по кількісних показниках Статуту ВКЛ 1588 р. Показано, що обидві пам'ятки права відрізняються значною нерівномірністю розподілення текстового матеріалу, при цьому їх коефіцієнти варіації приблизно збігаються.

У цілому цінність цього дослідження полягає у кількісному оцінюванні вказаної пам'ятки права, що дає змогу перейти від описового характеру до цифрового аналізу нормативно-правових актів та виявити сфери правового регулювання, яким була приділена найбільша увага.

Ключові слова: Козацько-еетьманська держава, універсали, грамоти, джерела права, кримінальна відповідальність, кількісні показники, пріоритетні напрямки, цивільне право.

ВСтУП. Актуальність теми дослідження пов'язана з тим, що в Україні проходять складні процеси реформування державної влади, органів управління та правової системи. На перебіг цих подій накладається криза, яка охопила політику, економіку, соціальну та культурну сфери життя українського суспільства. Така ситуація потребує розробки нових моделей суспільно- політичного устрою країни для мінімізації негативних наслідків кризових явищ. У таких умовах доцільно використати правовий досвід, накопичений у попередній історичний період, який дозволить вибрати модель соціально-політичного устрою, тісно пов'язану із традиціями українського державотворення. Інтерес до "Прав, за якими судиться малоросійський народ" 1743 р. (далі 